gainscores (before or after treatment), however, there was a significantly higher variance in the pyritinol group in four parameters. The latter findings suggest medication effects for a not as yet specifiable subpopulation. The problem of how to define objective indications for a psychoactive drug was therefore considered to be the most difficult task for such a study.

\section{REFERENCES AND NOTES}

1. Arthur, G.: Point Scale of Performance Tests: Revised Form, Vol. II (The Psychological Corporation, New York, 1947)

2. Benton, A. L.: Der Benton-Test (Huber, Berne, 1968)

3. Brickenkamp, R.: Test d2. Aufmerksamkeits-Belastungs-Test (Hogrefe, Göttingen, 1968)

4. Chistoni, G. C., de Perrot, E., and Niederberger, W.: A la recherche de nouvelles méthodes d'expérimentation des médicaments psychotropes. Int. Pharmacopsychiat. Top. Prdd. 5: 54 (1970).

5. Darge, W., Liss, E., and Oeff, K.: Untersuchungen zur Pharmakokinetik und zum Metabolismus von ${ }^{35}$ S-Pyrithioxin beim Menschen. Drug Res., 9 (1969)

6. Fish, B.: Methodology in child psychopharmacology. Psychopharmacology, p. 989 (National Institute of Mental Health, Washington, D. C., 1968).

7. Fisher, S.: Child Research in Psychopharmacology. Charles C Thomas, Springfield, Ill. (1959).

8. Hardesty, F. P., and Priester, H. J.: Hamburg-Wechsier Intelligenztest für Kinder (Huber, Bern, 1966).

9. Hiskey, M. S.: Hiskey-Nebraska Test of Learning Aptitude. (Union College Press, Lincoln, Neb., 1966).

10. Hoffecker, E.: Erfahrungen mit Encephabol in der kinderärztlichen Praxis. Ther. Gegenw., 7: 913 (1964)

11. Hofovy, R., Enenkel, H. J., Gillissen, J., et al.: Zur Pharmakologie des Vitamins $B_{6}$ und seiner Derivate. Drug Res., 14: 26 (1964).

12. Jacobs, R.: Zur Psychopharmakotherapie bei sogenannten geistig behinderten Kindern unter besonderer Berücksichtigung der Encephabol-Medikation. Kinderärztl. Prax., 37: 111 (1969).

13. Kleinpeter, U., and Rösler, H. D.: Encephabol bei hirnorganisch leistungsgeminderten Normalschulkindern. Pädiatr. Grenzgeb., 7: 1 (1968).

14. Kohlmann, T., and Rett, A.: Klinische und psychologische Untersuchungen über die Wirkung von Pyrithioxin bei gehirngeschädigten Kindern und Jugendlichen. Med. We., 43: 2180 (1963).

15. Körner, $F_{\text {, }}$ and Nowak, $\mathrm{H}_{.}$: Zur Vitamin $\mathrm{B}_{6}$-und Antivitamin $\mathrm{B}_{6}$-Wirksamkeit von Pyridoxol-Derivaten unter besonderer Berücksichtigung des Pyrithioxins. Drug Res., 17: 572 (1967).

16. Latz, A.: Cognitive test performance of normal human adults under the influence of psychopharmacological agents: A brief review. Psychopharmacology, p. 83 (National Institute of Mental Health, Washington, D. C., 1968).
17. Lobrot, M.: Forschungen zur Legasthenie in Frankreich. Leseund Rechtschreibschwäche von Schulkindern. Hrsg. Ingelkamp K., Berlin, 1966).

18. Mark, H. J.: Psychodiagnostics in patients with suspected minimal cerebral dysfunction(s) (MBD). Minimal brain dysfunction in children. ( $N+S D C P$, United States Department of Health, Education and Welfare, Public Health Service Publication No. 2015, 1969).

19. Moulding, T., Onstad, G. D., and Sbarbaro, J. A.: Supervision of outpatient drug therapy with the medication monitor. Ann. Intern. Med., 73: 559 (1970).

20. Nievoll, A.: Behandlung von gehirngeschädigten Kindern. Aerztl. Prax., 40: 1664 (1964)

21. Nowak, H., and Schorre, G.: Untersuchungen zum Metabolismus von Pyrithioxin. Drug Res., 19: 11 (1969).

22. Oeff, K., Darge, W., and Liss, E.: Zum pharmakokinetischen Verhalten von ${ }^{35}$ S-Encephabol. Radioisotope in Pharmakokinetik und klinischer Biochemie, p.65 (Schattauer, Stuttgart, 1968).

23. Quadbeck, G., Landmann, H. R., Sachsse, W., and Schmidt, I.: Der Einfluss von Pyrithioxin auf die Blut-Hirnschranke. Med. Exp., 7: 144 (1962).

24. Radmayr, E.: Zur Therapie der Entwicklungsretardierung mit Encephabol. Landarzt, 43: 883 (1967).

25. Rickels, K., Cattell, R. B., Weise, C., et al.: Controlled psychopharmacological research in private psychiatric practice. Psychopharmacologia, 9: 288 (1966)

26. Sartory, G., and Rust, J.: The effects of a single administration of elitoxine on several psychological tests. Psychopharmacologia, 29/4: 365 (1973).

27. Stoll, E., Stoll, K.-D., and Gierhake, R.: Einfluss des Pyritinol-hydrochlorid auf das Leistungsverhalten konzentrations-schwacher Kinder. (Vortrag Jahrestagung Oesterreichische Gesampte für Kinderheilkunde, Salzburg, 1973).

28. Stoll, K.-D.: Personal communication.

29. Stroop, J. R.: Studies of interference in serial verbal reactions. J. Exp. Psychol., 18: 643 (1935).

30. Taber, B.: Proving New Drugs (Geron-X, Los Altos, Calif., 1969)

31. Terman, L. M., and Merrill, M. A.: Revised Stanford-Binet Intelligence Scale. (Houghton Mifflin, Boston, 1960).

32. Turner, P.: Critical flicker frequency and centrally-acting drugs. Brit. J. Ophthalmol., 52: 245 (1968).

33. Wälti, U., Salvisberg, H., and Auf der Maur, P.: Das kognitive Funktionsmuster bei Kindern Mit Trisomie 21. Schweiz. Z. Psychol., 32: 122 (1973).

34. Encephabol, E. Merck, Darmstadt.

35. The authors wish to thank especially to Drs. Y. Neumann and K. D. Stoll for their substantial help with the technical organization of the study and the evaluation of data.

36. This research was supported by E. Merck, Darmstadt and the "Schweizerischer Nationalfonds zur Förderung der wissenschaftlichen Forschung," Project No. 4.62.72.

37. Requests for reprints should be addressed to: U. Wälti, Ph.D., Abteilung für Entwicklungsstörungen, Medizinische Kinderklinik der Universitat Bern, Inselspital, 3000 Berne (Switzerland).

38. Accepted for publication May 7, 1975.
Cystic fibrosis duodenal fluids exocrine glands polyamines saliva spermidine spermine sweat

\title{
Polyamines in Cystic Fibrosis
}

\author{
F. A. MCEVOY(25) AND C. B. HARTLEY \\ University of Birmingham, Institute of Child Health, Birmingham, United Kingdom
}

\section{Extract}

Polyamine concentrations have been measured in blood samples from a series of cystic fibrosis (CF) patients and control subjects. Analyses were made by a fluorometric method, in which the amines were reacted with dansyl chloride and separated by thin layer chromatography on Kieselguhr. There was no significant difference between the polyamine concentrations of blood samples from CF patients and control subjects. Also, the spermidine-spermine ratio was similar in both groups. Polyamines were also analyzed in exocrine fluids, and although none could be detected in either CF or control sweat or saliva, significant amounts of spermine and spermidine were present in all samples of bile and duodenal fluids. It thus seems likely that the biliary route is a significant pathway in the human for excretion of polyamines.

\section{Speculation}

The observation that polyamines are excreted in considerable concentrations via the bile in children may be of interest in view of the reports of elevated urinary polyamine concentrations in neoplastic states. Since measurable amounts of spermine and spermidine 
were detected in all six bile preparations available for this study, analysis of these substances in bile may be of benefit in particular cases.

The polyamines are widely distributed in living tissues (20) and are thought to be of importance in a number of cellular functions, including protein synthesis of the ribosome level and membrane stability $(3,11,16,19)$. The metabolism of these compounds is of interest in the study of the genetic disease, since elevated blood spermidine levels have recently been reported in CF patients and also in $C F$ heterozygotes $(1,15)$. In this study polyamine concentrations have been measured in blood samples from a series of CF patients and control subjects. In view of the fact that the pathology of CF is concerned mainly with the exocrine glands, it was of interest to test for the presence of polyamines in sweat, saliva, and duodenal fluids.

\section{MATERIALS AND METHODS}

Analysis of the polyamines was made by a fluorometric method, in which the amines were reacted with dansyl chloride and separated by thin layer chromatography. The paper electrophoretic method of Raina (14) and the ninhydrin method of Hammond and Herbst (9) were both found to be unsatisfactory for measurement of spermine and spermidine in blood, possibly because of the low concentrations of polyamines in this material.

Tissues were extracted with $10 \%$ trichloroacetic acid, and the polyamines were isolated by the alkaline-butanol extraction procedure of Raina (14). Polyamine preparations were dansylated (2) and the dansyl derivatives were extracted into benzene, dried in an Evapomix (2l), and separated by thin layer chromatography on Kieselguhr $G$ (22), using cyclohexane-ethyl acetate $3: 1 \mathrm{v} / \mathrm{v}$, as solvent. Dansyl amines were quantitated by elution with methanol containing 5\% ammonia, followed by fluorometry (18). All experiments were run in duplicate. Experiments were done on paired samples, i.e., a sample of CF blood was analyzed together with a control sample matched as closely as possible in terms of age and sex. Standards were drawn through the whole purification procedure in each experiment. In agreement with other workers, there were some inevitable losses in the $n$-butanol extration procedure $(7,9)$ and the overall recovery was between $50 \%$ and $70 \%$ in different experiments. This variation in recovery did not affect the accuracy of the tissue estimations, since in all experiments CF and control tissues were paired and there was considerably less variation within batches than that between batches. The coefficient of variation was less than $5 \%$ for standards and less than $10 \%$ for tissue samples. No significant improvement in recovery was obtained by further extraction of the tissues with trichloroacetic acid. In all cases the recovery of spermine paralleled that of spermidine.

Blood samples, containing $10 \mathrm{mM}$ citrate as anticoagulant, were extracted within $1 \mathrm{hr}$ of obtaining the specimens from the patients. Gall bladder contents were obtained at autopsy and stored at $-20^{\circ}$ before extraction. None of the CF patients were seriously ill at the time of obtaining samples, and there was no significant correlation between their blood polyamine concentrations and their clinical scores. Control subjects were matched as closely as possible in terms of age and sex with the CF patients. Duodenal fluid specimens were pancreozymin-secretin-stimulated samples obtained during diagnostic incubation studies.

The Kieselguhr chromatographic system used gave a complete separation of Dansyl spermine and spermidine from other fluorescent substances (Fig. 1). The Dansyl derivatives of putrescine, cadaverine, and ammonia had greater $R_{F}$ values than spermidine in this system, and did not interfere with the estimation of spermine and spermidine.

\section{RESULTS}

As shown in Table 1 there was no significant difference between the blood polyamine concentrations of blood samples from CF

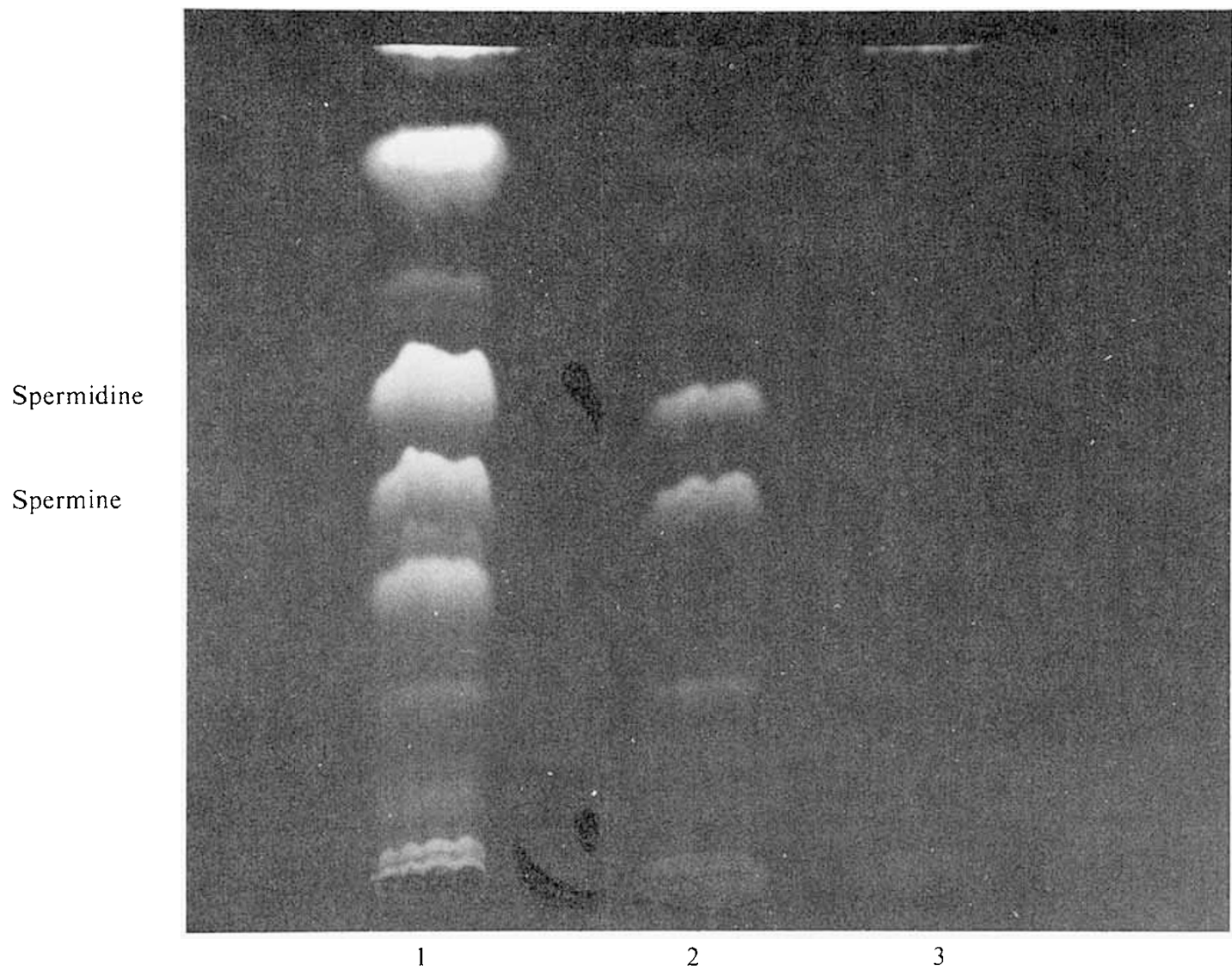

Fig. 1. Thin layer chromatography of dansylated polyamines on Kieseiguhr. Samples of whole blood $(I)$, standard spermine and spermidine (2) and a reagent blank (3) were extracted with $10 \%$ trichloroacetic acid theated with alkaline butanol, and reacted with dansyl chloride as described under Methods. The developing solvent was cyclohexane ethyl acetate, $3: 1 \mathrm{v} / \mathrm{v}$. 
Table 1. Polyamine concentrations in whole blood

\begin{tabular}{lccc}
\hline \multicolumn{1}{c}{ Subjects } & $\begin{array}{c}\text { Spermine } \\
\pm \mathrm{SD} \\
(\mu \mathrm{g} / \mathrm{ml})\end{array}$ & $\begin{array}{c}\text { Spermidine } \\
\pm \mathrm{SD} \\
(\mu \mathrm{g} / \mathrm{ml})\end{array}$ & $\begin{array}{c}\text { Spermidine/ } \\
\text { spermine } \\
\text { ratio } \pm \mathrm{SD}\end{array}$ \\
\hline Cystic fibrosis $(12)$ & $1.26 \pm 0.72$ & $1.29 \pm 0.57$ & $1.07 \pm 0.28$ \\
Control (12) & $1.10 \pm 0.27$ & $1.17 \pm 0.57$ & $1.01 \pm 0.32$ \\
\hline
\end{tabular}

Table 2. Polyamine concentrations in exocrine fluids ${ }^{1}$

\begin{tabular}{lcc}
\hline \multicolumn{1}{c}{ Contents } & $\begin{array}{c}\text { Spermidine, } \\
\mu \mathrm{g} / \mathrm{ml}\end{array}$ & $\begin{array}{c}\text { Spermine, } \\
\mu \mathrm{g} / \mathrm{ml}\end{array}$ \\
\hline Autopsy gall bladder & & \\
No. (CF) & 78.6 & 88.0 \\
No. 2 (CF) & 38.3 & 27.5 \\
No. 3 (Control) & 18.0 & 15.6 \\
No. 4 (Control) & 11.1 & 16.6 \\
Duodenal fluids & $1.91 \pm 0.32$ & $1.27 \pm 0.67$ \\
Control (5) \pm SD & 19.0 & 29.0 \\
CF, patient $A$ & 15.0 & 20.0 \\
CF, patient $B$ & & \\
Sweat & $<0.25$ & $<0.25$ \\
CF (4) & $<0.25$ & $<0.25$ \\
Control (4) & & $<0.05$ \\
Saliva & $<0.05$ & $<0.05$ \\
CF (4) & $<0.05$ & \\
Control (4) & & \\
\hline
\end{tabular}

${ }^{2} \mathrm{CF}$ : cystic fibrosis. Figures in parentheses refer to the number of samples in each group.

patients and control subjects. Also, the spermidine-spermine ratio was similar in both groups. These data must almost entirely reflect the erythrocyte polyamine concentrations, since analysis of different blood cell fractions separated by a ficoll gradient procedure (10) showed that $95 \%$ of the blood polyamine was associated with erythrocytes. Blood plasma contained negligible amounts of polyamines, as reported previously (13).

The polyamine concentrations in other human fluids are summarized in Table 2. The gall bladder contents were obtained from four patients at autopsy. Sweat samples were obtained by pilocarpine-induced iontophoresis (8), and mixed saliva was obtained by citric acid stimulation (5). Polyamines were found in all samples of bile and duodenal fluid, but none could be detected in CF or control sweat or saliva. The concentration of polyamines is raised in the two CF gallbladder specimens. It is not clear whether this is related to the concentrated nature of CF fluids $(6,12)$, or whether it is due to a specific metabolic effect.

Polyamine concentrations were also increased in CF duodenal samples in comparison with controls. This, however, is almost certainly a reflection of diminished pancreatic fluid output in CF, which is characteristic of the disease (12).

\section{DISCUSSION}

Elevated polyamines concentrations have been reported in $\mathrm{CF}$ using an automated ion exchange technique for analysis $(1,15)$. In this study, using a thin layer chromatographic technique, no significant difference could be observed between control and $C F$ blood polyamine concentrations. In view of the considerable difference between the two methods of analysis, the possibility exists that the difference between this present data and that of Rennert and associates $(1,15)$ is a methodologic one.

These data suggest that the polyamines are not a general constituent of exocrine fluids. The concentrations of polyamines found in the duodenal fluid are consistent with their being of biliary origin. Although excretion of spermine and spermidine via the gall bladder has not previously been characterized, it is not unexpected since there does not appear to be a pathway of catabolism of these amines in the human (20). If the concentrations of polyamines in the bile of the controls investigated in this study are proven to be the normal mean value, then about $1.5 \mathrm{mg}$ of each of the polyamines would be excreted per day via the biliary route based on a mean bile volume of $100 \mathrm{ml}$ (4) which compares with a mean daily excretion of $2.5-3 \mathrm{mg} / 24 \mathrm{hr}$ in the urine (17). It thus seems likely that the biliary route is a significant pathway in the human for excretion of polyamines. In this study we have measured only free polyamines. It is possible that there is a further pool of acetylated polyamines in bile. The possibility of the gall bladder polyamines having been of bacterial origin is most unlikely since the duodenal and gall bladder specimens were all essentially sterile by routine bacteriologic examination (23).

The recent demonstration that excretion of polyamines is increased in cancer patients (17) suggests that measurement of urinary polyamines may be of importance in cancer diagnosis. Since, in this study, measurable amounts of spermine and spermidine were found in all the six bile preparations available, measurement of biliary excretion of these substances may also be of use in particular cases.

\section{SUMMARY}

Polyamines were analyzed in whole blood samples from cystic fibrosis patients and matched control subjects. Spermine and spermidine concentrations were similar in both groups. Exocrine fluids were tested for the presence of polyamines, and significant concentrations were found in bile and duodenal fluid, but not in sweat or saliva.

\section{REFERENCES AND NOTES}

1. Arvanitakis, S. N., Mangos, J., McSherry, N., Rennert, O. M., and La Pointe, D.: Role of polyamines in cystic fibrosis. Pediat. Res., 7: 336 (1973).

2. Bachrach, U., Don, S., and Wiener, H.: Polyamines and tumour cells: The effect of transformation of chick fibroblasts by Rous sarcoma virus on polyamine levels. Biochim. Biophys. Res. Commun., 55: 1035 (1973).

3. Cohen, S. S.: Introduction to the Polyamines (Prentice Hall, Englewood Cliffs, N.J., (1971).

4. Davenport, H. W.: Physiology of the Digestive Tract Ed. 2 (Year Book Medical Publishers, Chicago, 1966).

5. di Sant'Agnese, P. A., Grossman, H., Darling, R. C., and Denning, C. R.: Saliva, tears and duodenal contents in cystic fibrosis of the pancreas. Pediatrics, 22: 507 (1958).

6. di Sant'Agnese, P. A., and Talamo, R.: Pathogenesis and physiopathology of cystic fibrosis of the pancreas. New Engl. J. Med., 277: 1287 (1967).

7. Dreyfus, G., Dvir, R., Harell, A., and Chayen, R.: Determination of polyamines in urine. Clin. Chim. Acta, 49: 65 (1973).

8. Gibson, L. E., and Cooke, R. E.: A test for concentration of electrolytes in sweat in cystic fibrosis of the pancreas utilising pilocarpine by iontophoresis. Pediatrics, 23: 545 (1959).

9. Hammond, J. E., and Herbst, E. J.: Analysis of polyamines by thin layer chromatography. Anal. Biochem., 22: 474 (1968).

10. Harris, R., and Ulsaojiofo, E. O.: Tissue typing using a routine one-step lymphocyte separation procedure. Brit. J. Haematol., 18: 229 (1968).

11. Herbst, E. J., and Bachrach, U. (Eds.): Metabolism and function of polyamines Ann. N.Y. Acad. Sci. 171 (3): (1970).

12. Johansen, P. G., Anderson, C. M., and Hadorn, B.: Cystic fibrosis of the pancreas: A generalised disturbance of water and electrolyte movement in exocrine lissues. Lancet, $i: 455$ (1968).

13. Raina, A. A.: Spermine and spermidine in normal human blood. Scand. J. Clin. Lab. Invest., 14:318 (1962).

14. Raina, A. A.: Studies on the determination of spermidine and spermine and their metabolism in the developing chick embryo. Acta Physiol. Scand., 60(suppl. 218): 1 (1963).

15. Rennert, O., Frias, J., and La Pointe, D.: Methylation of RNA, and polyamines in cystic fibrosis. In: J. Mangos and R. Talamo: Fundamental Problems of Cystic Fibrosis and Related Diseases, p. 41 (Intercontinental Medical Book Corp., N. Y., 1973).

16. Russell D. H. (Ed.): Polyamines in Normal and Neoplastic Growth (Raven Press, N. Y., 1973).

17. Russell, D. H.: Increased polyamine concentration in the urine of human cancer patients. Nature, 233: 144 (1971).

18. Seiler, N.: Use of the dansyl reaction in biochemical analysis. Methods Biochem. Anal., 18: 259 (1970).

19. Stevens, L.: The biochemical role of naturally occurring polyamines in nucleic acid synthesis. Biol. Rev., 45: 1 (1970).

20. Tabor, H., and Tabor, C. W.: Spermidine, spermine and related amines. Pharmacol. Rev., 16: 245 (1964). 
21. Obtained from Buchler Instruments, N. J.

22. Kieselguhr G (Merck) obtained from Anderman \& Co., Ltd., East Molesey, Surrey, U. K.

23. The authors are grateful to $P$. Turner for bacteriologic analyses

24. This work was supported by a grant from the Cystic Fibrosis Research Trust. The authors are grateful to Professor C. M. Anderson for encouragement and to

Copyright (c) 1975 International Pediatric Research Foundation, Inc.
Drs. M. Goodchild, M. Brueton, and N. Evans for assistance in obtaining specimens.

25. Requests for reprints should be addressed to: F. A. McEvoy, Ph.D., Department of Biochemistry, School of Biological Sciences, University of Sussex, Falmer, Brighton, Sussex, (U. K.)

26. Accepted for publication May 8, 1975

Pediat. Res. 9: 724-729 (1975)

$\epsilon$-Amino caproic acid

cystic fibrosis

degranulation of leukocytes

enzymes

Printed in U.S.A.

\title{
Demonstration of Human Leukocyte Degranulation Induced by Sera from Homozygotes and Heterozygotes for Cystic Fibrosis
}

\author{
ELAINE J. CONOD, (32) JAMES H. CONOVER, AND KURT HIRSCHHORN \\ Department of Pediatrics, Division of Medical Genetics, Mount Sinai School of Medicine of the City Universitv \\ of New York, New York, New York, USA
}

Extract

The ability of $\epsilon$-amino caproic acid (EACA)-treated normal serum and of cystic fibrosis (CF)-affected and carrier sera to promote the release of Iysosomal enzymes from sensitized human polymorphonuclear leukocytes (PMN) was assessed through the measurement of $\beta$-glucuronidase and myeloperoxidase acitivity after exposure of these cells to the various test sera. This study was initiated to extend the analogies between preciliary dyskinesia factor (pre-CDF), separated from the cell-free media of cultures derived from CF homozygous and heterozygous individuals, and C3a anaphylatoxin. The extent of lysosomal degranulation of human PMN exposed to fresh untreated sera of each of five controls, seven CF homozygotes, and eight heterozygotes, as expressed by the amount of $\beta$-glucuronidase released, was $7.84 \%( \pm \mathbf{0 . 9 3 4})$ for control sera, $14.01 \%( \pm 1.79)$ for CF-affected sera, and $10.61 \%$ $( \pm 1.43)$ for heterozygous sera. The difference between $\mathrm{CF}$ homozygotes and control subjects is significant $(P<0.001)$, as is the difference between CF-affected and carrier individuals $(0.001<P$ $<0.005)$ and between control subjects and carriers $(0.001<P<$ 0.005 ), when $\beta$-glucuronidase release is measured. Analogously, values of myeloperoxidase released by the three groups studied reflect differences similar to those of $\beta$-glucuronidase. However, the differences between control subjects and $C F$ heterozygous individuals are not significant. Treatment of these sera with $1 \mathrm{M}$ EACA gave values for $\beta$-glucuronidase and myeloperoxidase release which are slightly reduced when compared with those obtained with fresh, untreated samples. EACA apparently reduces the activity of $\beta$-glucuronidase released from PMN. Amicon filtration studies of these serum samples demonstrated that degranulating ability and the presence of ciliary dyskinesia, as assessed by rabbit tracheal bioassay, are not always associated. Therefore, the relationship between pre-CDF and the degranulator activity in native $\mathrm{CF}$-affected and carrier sera is unclear, in part because of the limitations inherent in the test systems employed.

\section{Speculation}

The pathophysiology of $C F$ can be explained by excessive degranulation of exocrine glandular cells, resulting in inspissation of their ducts. The finding of degranulator molecules in CF sera allows for a test of this hypothesis. The possibility exists that this degranulating activity, as well as the molecules responsible for ciliary dyskinesia, whether they are the same or different molecular species, may represent an excess of normal products. These molecules, related to $\mathrm{C} 3 \mathrm{a}$ anaphylatoxin and/or kinins, are present in excess in $C F$ because of the deficiency of an enzyme which normally controls their level by inactivation.

Cystic fibrosis is an autosomal recessive disorder occurring predominantly in children and young adults in the Caucasian population. The presence of material in the serum of CF patients which produces dyskinesia in the normal beating pattern of rabbit tracheal cilia was first described by Spock and his associates (18). This ciliary dyskinesia factor (CDF) was found in sera of both CF-affected individuals and obligate heterozygotes for CF. These observations were confirmed in our laboratory using a modification of Spock's original assay system (8), and by Bowman and coworkers (3) using oyster gill preparations in place of the rabbit tracheal explants. This CDF has also been demonstrated to be present in the cell-free medium obtained from phytohemagglutinin-stimulated leukocytes of CF patients and their parents, as well as in the cell-free medium of long term lymphoid lines derived from CF-affected and carrier subjects (7). In addition, the cell-free medium from cultured skin fibroblasts from homozygotes and heterozygotes for $C F$ demonstrates CDF in both the oyster gill system (10) and the rabbit tracheal bioassay system, the latter in the presence of human immunoglobulin $(\operatorname{lgG})(2)$. Previous reports from our laboratory have indicated that the substance responsible for the pathophysiology of CF may be the complement component $\mathrm{C} 3 \mathrm{a}$ anaphylatoxin or a $\mathrm{C} 3 \mathrm{a}-\mathrm{dike}$ molecule (9). Among other properties, anaphylatoxins have been shown to interact with human PMN treated with cytochalasin B, a fungal metabolite, and to promote extracellular release of lysosomal enzyme from these cells $(14,15)$.

Based on analogies drawn between C3a and pre-CDF (9) and on the above findings concerning anaphylatoxins (14), as well as on the known similarities between the biologic activities of $\mathrm{C} 3 \mathrm{a}$ and $\mathrm{C} 5$ a anaphylatoxins, the native degranulating ability of sera from 